WRI-93-R021

\title{
REMOVAL OF MERCURY FROM POWDER RIVER BASIN COAL BY LOW-TEMPERATURE THERMAL TREATMENT
}

By

Norman W. Merriam

July 1993

Work Performed Under Cooperative Agreement

DE-FC21-93MC30126

For

U.S. Department of Energy

Office of Fossil Energy

Morgantown Energy Technology Center

Morgantown, West Virginia

By

Western Research Institute Laramie, Wyoming
This report was prepared as an account of work sponsored by an agency of the United States Government. Neither the United States Government nor any agency thereof, nor any of their employees, makes any warranty, express or implied, or assumes any legal liability or responsibility for the accuracy, completeness, or usefulness of any information, apparatus, product, or process disclosed, or represents that its use would not infringe privately owned rights. Reference herein to any specific commercial product, process, or service by trade name, trademark, manufacturer, or otherwise does not necessarily constitute or imply its endorsement, recommendation, or favoring by the United States Government or any agency thereof. The views and opinions of authors expressed herein do not necessarily state or reflect those of the United States Government or any agency thereof. 


\section{DISCLAIMER}

Portions of this document may be illegible in electronic image products. Images are produced from the best available original document. 


\section{ACKNOWLEDGEMENT}

This report was prepared with the support of the U.S. Department of Energy (DOE), Morgantown Energy Technology Center, under Cooperative Agreement Number DE-FC-93MC30126. However, any opinions, findings, conclusions, or recommendations expressed herein are those of the author(s) and do not necessarily reflect the views of DOE.

The author wishes to thank Joyce Holbrook for her usual dedicated work in preparing the manuscript for this report. 


\section{SUMMARY}

This report describes work conducted at Western Research Institute (WRI) to remove mercury from Powder River Basin (PRB) coal as part of the research performed under Task 2.1, Development and Optimization of a Process for the Production of a Premium Solid Fuel from Western U.S. Coals, of the 1993 Annual Project Plan. In the tests minus 16 mesh PRB coal was fed to a bench-scale fluidizedbed reactor where it was heated by contact with carbon dioxide fluidizing gas. A side stream of the gas from the reactor was passed through traps containing activated carbon where mercury driven from the coal was collected. The feed coal (which contains about 0.062 milligrams of mercury/kilogram of coal), the fines elutriated from the reactor, the activated carbon, and the condensed water from the reactor were analyzed for mercury. The solid products were analyzed using cold vapor atomic adsorption spectroscopy (ASTM D3684) while the water was analyzed using U.S. Environmental Protection Agency (EPA) Method 245.1 which is based upon reduction of mercury to elemental form followed by adsorption at a wave length of 253.7 nanometers.

The results of these tests show that about 70 to $80 \mathrm{wt} \%$ of the mercury is removed from the coal when the temperature is raised from about $300^{\circ} \mathrm{F}\left(149^{\circ} \mathrm{C}\right)$ to about $550^{\circ} \mathrm{F}\left(288^{\circ} \mathrm{C}\right)$. The remaining $20 \mathrm{wt} \%$ of the mercury remains in the char at temperatures up to about $1100^{\circ} \mathrm{F}\left(593^{\circ} \mathrm{C}\right)$. About $0.5 \mathrm{wt} \%$ of the mercury in the feed coal is condensed with water recovered from the coal. Nearly all of the mercury driven from the coal remains in the gas stream. Fines elutriated from the reactor contain about the same concentration of mercury as the feed coal.

We used mercury balances to gauge the reliability of our results. We obtained closures of $63,75,82,105$, and $110 \%$ for the five tests we used to determine our results for this report. Other researchers have reported that closures within $20 \%$ of 100 are used as criteria to determine the acceptability of data for trace element work because of the very low concentrations involved. 


\section{TABLE OF CONTENTS}

$\underline{\text { Page }}$

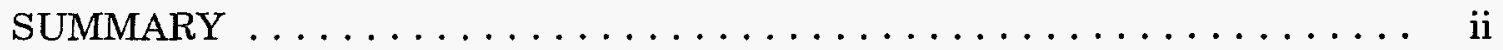

LIST OF TABLES $\ldots \ldots \ldots \ldots \ldots \ldots \ldots \ldots \ldots \ldots \ldots \ldots \ldots \ldots$ iv

LIST OF FIGURES $\ldots \ldots \ldots \ldots \ldots \ldots \ldots \ldots \ldots \ldots \ldots \ldots \ldots$

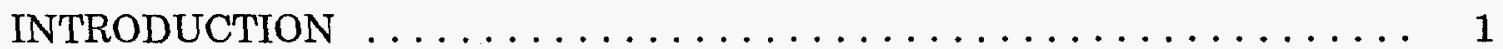

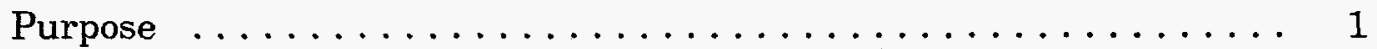

Impact of Clean Air Act Amendments ................ 1

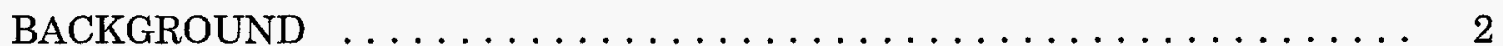

REMOVAL OF MERCURY FROM POWDER RIVER BASIN COAL $\ldots \ldots \ldots \quad 5$

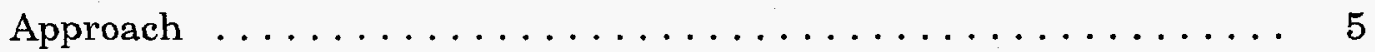

Description of the Testing System ................ 7

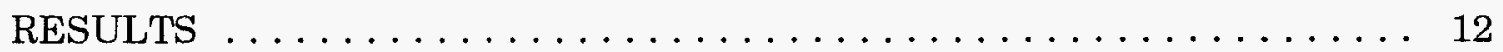

PROPOSED MERCURY REMOVAL PROCESS $\ldots \ldots \ldots \ldots \ldots \ldots \ldots 17$

Proposed Process $\ldots \ldots \ldots \ldots \ldots \ldots \ldots \ldots \ldots \ldots \ldots \ldots \ldots \ldots$

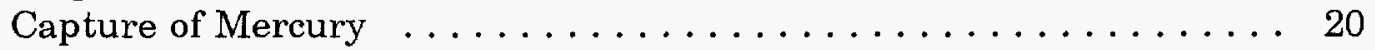

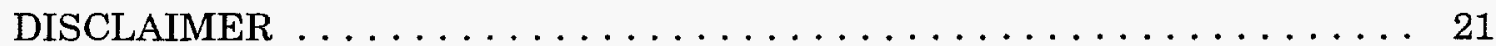

REFERENCES $\ldots \ldots \ldots \ldots \ldots \ldots \ldots \ldots \ldots \ldots \ldots \ldots \ldots \ldots \ldots \ldots \ldots \ldots \ldots, 22$ 


\section{LIST OF TABLES}

$\underline{\text { Table }}$

Page

1. Distribution of Air Toxic Elements in Effluents from Coal-Fired

Power Plants . . . . . . . . . . . . . . . . . .

2. Volatile Trace Elements in Powder River Basin Coal and Chars

from Pyrolysis ........................ 6

3. Composition of Powder River Basin Coal from the Eagle Butte Mine . 7

4. Composition of Air-Dried Coal Used for Tests . . . . . . . . . . 10

5. Summary of Conditions Used for Tests to Remove Mercury from Powder River Basin Coal . . . . . . . . . . . . . . . . . . . . . . 10

6. Coal Balances for Tests Conducted to Remove Mercury from Powder River Basin Coal . . . . . . . . . . . . . . . . . . . 13

7. Mercury Balances for the Tests Conducted to Remove Mercury from Powder River Basin Coal . . . . . . . . . . . . . . 13

8. Comparison of Distribution of Coal Components and Mercury . . . . 14 


\section{LIST OF FIGURES}

Figure

Page

1. Bench-Scale Fluidized-Bed Dryer Used for Mercury Removal Tests . . 8

2. Sampling System Used to Remove Mercury from a Side-Stream of Effluent Gas ........................ 9

3. Analyses and Plots Used to Detect Breakthrough of Mercury . . . . 11

4. Temperature at which Mercury is Released from Powder River Basin Coal . . . . . . . . . . . . . . . . . . . 12

5. Most of the Mercury in Powder River Basin Coal is Driven from the Coal at Temperatures of 300 to $550^{\circ} \mathrm{F} \ldots \ldots \ldots \ldots \ldots$

6. Removal of Water Using a Fluidized-Bed Dryer . . . . . . . . . . . 16

7. Partial Decarboxylation of Powder River Basin Coal and Removal of Mercury .................... 16

8. Removal of Mercury with Partial Decarboxylation . . . . . . . . . 17

9. Removal of Mercury and Capture by Low-Temperature Scrubbing . . 18

10. Removal of Mercury and Capture by Medium-Temperature Adsorption 19 


\section{INTRODUCTION}

\section{$\underline{\text { Purpose }}$}

The purpose of this report is to summarize the work we have done to develop a process to remove mercury from Powder River Basin (PRB) coal. This work was conducted in anticipation of the regulation of emission of mercury from coal-fired power plants when the U.S. Environmental Protection Agency (EPA) completes studies and issues regulations as required by the Clean Air Act Amendments of 1990 (CAAA).

\section{Impact of Clean Air Act Amendments}

The Clean Air Act Amendments of 1990 require a new evaluation of the electric utility industry emissions of hazardous air pollutants (Chow et al. 1992).

The acid rain title requires 110 power plants having capacities greater than 100 megawatts to reduce $\mathrm{SO}_{2}$ emissions to less than $2.5 \mathrm{lb}$ of SO $\mathrm{S}_{2}$ /million Btu by 1995 . All power plants having capacity greater than 25 megawatts must reduce $\mathrm{SO}_{2}$ emissions to less than $1.2 \mathrm{lb}$ of $\mathrm{SO}_{2} /$ million Btu by the year 2000 . Also, the total emissions are not allowed to increase after 2000 so utilities must reduce the emissions per unit to allow for future growth in capacity (Braine and Mann 1992). Many coals contain sufficient sulfur to result in emissions of 3 to $4 \mathrm{lb}$ of $\mathrm{SO}_{2} /$ million Btu, so many power plants are faced with the choices of either switching fuels, blending fuels, or installing scrubbers.

CAAA establish nitrogen oxides $\left(\mathrm{NO}_{\mathrm{x}}\right)$ emission reduction requirements for the control of acid rain, and also implement radical changes in treatment of $\mathrm{NO}_{\mathrm{x}}$ as a nonattainment pollutant. Title IV, control requirements, target a 2-million-ton per year reduction. To achieve the 2-million-ton reduction goal, EPA has been directed to establish the $\mathrm{NO}_{\mathrm{x}}$ emission limit at $0.45 \mathrm{lb}$ of $\mathrm{NO}_{\mathrm{x}} /$ million Btu for tangentially fired boilers and $0.50 \mathrm{lb}$ of $\mathrm{NO}_{\mathrm{x}} /$ million Btu for dry bottom, wall-fired boilers. However, EPA can set higher limits if these rates cannot be achieved using only low $\mathrm{NO}_{\mathrm{x}}$ burners. Affected units will not be required to install additional $\mathrm{NO}_{\mathrm{x}}$ emission control beyond low $\mathrm{NO}_{\mathrm{x}}$ burners.

Nearly all coal contains approximately from 1-2 wt \% of fuel bound nitrogen on a moisture-ash-free basis, equivalent to $2-4 \mathrm{lb} \mathrm{NO}_{\mathrm{x}} /$ million Btu. Depending upon the combustion conditions, varying fractions of this nitrogen are converted to $\mathrm{NO}_{\mathrm{x}}$. Rough estimates show approximately $80 \%$ of the $\mathrm{NO}_{\mathrm{x}}$ is derived from fuel bound nitrogen (Electric Power Research Institute 1992). 
Five studies which affect electric utilities are mandated: a 3-year study to address the hazards to public health associated with emissions from fossil-fuel power plants (after compliance with the acid rain provisions of the Act); a 4-year evaluation of mercury emissions, their effect on human health and the environment, and the availability and cost of potential control technology; a 3-year mercury study conducted by the National Institute of Environmental Health Sciences to define health and environmental thresholds for mercury; a 3-year study of atmospheric deposition rates, impacts on public and environmental health and water quality effects of air toxics on the Great Lakes and coastal water bodies; and a study on residual risk methods. EPA is directed to regulate the utility industry for air toxics only if its 3-year study indicates that such regulation is necessary and appropriate.

The CAAA have identified 189 hazardous air pollutants, of which 13 elements and their compounds have been commonly found in coal. These elements are antimony, arsenic, beryllium, cadmium, chlorine, chromium, cobalt, fluorine, lead, manganese, mercury, nickel and selenium. In addition to these specific elements, radionuclides are also listed as hazardous air pollutants which are known to exist in coal.

\section{BACKGROUND}

In a study conducted for the U.S. Department of Energy (DOE) to review the effectiveness of removal of trace elements from coal, Jacobsen et al. (1992) concluded that certain trace elements, such as arsenic, chlorine, fluorine, mercury, antimony, and selenium are difficult to control by conventional postcombustion capture and are prime candidates for removal by precombustion techniques. Germani and Zoller (1988) reported a sampling and analysis procedure for determining vapor-phase concentrations of arsenic, selenium, bromine, iodine, and mercury in the stack of a coal-fired power plant. They reported the percentages of those elements present in the vapor phase as arsenic, $0.7-52 \%$; selenium, $59 \%$; bromine, $98 \%$; iodine, $>99 \%$; and mercury, $98 \%$. Activated coconut-shell charcoal washed in nitric acid was successfully used to capture mercury from a stream of noncondensible gas.

Arsenic and mercury are commonly viewed as posing the greatest risk to human health and the ecosystem. Arsenic, for example, is found in coal in the range of 5 to $15 \mathrm{ppm}$ where it is associated with the pyrite in the coal as well as existing within the organic matrix of the coal as an organometallic. Upon combustion, arsenic often ends up concentrated on the fly ash, and is very difficult to remove in postcombustion removal systems. Many other trace toxics have similar problems. Mercury is known to migrate through hot filters and electrostatic precipitators. 
Lindqvist (1986) presented a schematic description of the mercury cycle and reports that mercury compounds in coal are probably bound to sulfur while municipal waste has a higher content of elemental or amalgamated mercury than fossil fuels. He also reports that mercury in coal is converted to elemental mercury during thermal decomposition at temperatures above $1300^{\circ} \mathrm{F}\left(704^{\circ} \mathrm{C}\right)$. Mercury in coal is associated with pyrite and cinnabar, and arsenic is associated with pyrite (Akers and Dospoy 1992).

Tests conducted with coal-fired power plants show that some of the air toxics are bound to particulates (Table 1). Those toxics can be removed from effluent gas by improving the efficiency of filters. However, mercury, chlorine, and selenium are not quantitatively captured with fly ash.

Table 1. Distribution of Air Toxic Elements in Effluents from Coal-Fired Power Plants, \% of element

Element

\begin{tabular}{ccc}
\multicolumn{2}{c}{ Three U.S. Power Plants } \\
\hline Bottom & Precipitator & Flue \\
Ash & Ash & Gas
\end{tabular}

Four Canadian Power Plants

Flue Gas

Gas

$\begin{array}{lrrrc}\text { Antimony } & 3 & 93 & 4 & 0.2-2.2 \\ \text { Arsenic } & <1 & 99 & <1 & 0.7-9.3 \\ \text { Beryllium } & 17 & 81 & 2 & - \\ \text { Cadmium } & 16 & 80 & 4 & -- \\ \text { Chlorine } & 16 & 4 & 80 & 49.0-99.0 \\ \text { Chromium } & 14 & 74 & 12 & 0.1-8.7 \\ \text { Cobalt } & 16 & 83 & 1 & 0.09-1.5 \\ \text { Fluorine } & 1 & 91 & 8 & -- \\ \text { Lead } & 10 & 82 & 8 & 0.2-2.4 \\ \text { Manganese } & 17 & 82 & 1 & 0.1-1.0 \\ \text { Mercury } & 2 & 0 & 98 & 79.0-87.0 \\ \text { Nickel } & 14 & 68 & 18 & -- \\ \text { Selenium } & 1 & 61 & 31 & 3.5-73.0 \\ \text { Uranium } & 18 & 81 & 1 & --\end{array}$

a U.S. National Committee for Geochemistry 1980

b Brown and Schmidt 1993 
Mercury is considered to be particularly hazardous to human health because of the toxicity of mercury and derivative compounds and also because of the dispersion mechanism in the environment. Mercury is released to the atmosphere by natural processes and by anthropogenic activities. More than $95 \%$ of the atmospheric mercury is in the elemental form (valence 0) which remains in the atmosphere for periods of 0.7 to 2 years (Nater and Grigal, 1992). Elemental mercury is insoluble in water and remains in the atmosphere until it is oxidized to a higher, water-soluble valence by ultraviolet radiation, interacts with ozone, or reacts with free radicals. Thus, the deposition of elemental mercury is global in nature. The particulate mercury, which is less than $5 \%$ of the atmospheric mercury, has relatively short residence time in the atmosphere and deposition is more local or regional. One-third of the mercury deposited in central Wisconsin is estimated to come from dry deposition of particulates (Fitzgerald et al. 1991).

Slemr and Langer (1992) reported the results of mercury measurements over the Atlantic Ocean from 1977 to 1990 . They concluded that the measurements show the atmospheric concentrations of mercury have increased $1.46 \pm 0.17 \%$ per year in the northern hemisphere. They also reported that these rates are consistent with the results of soil, peat-bog, and lake-sediment analyses.

Swain et al. (1992) studied the mercury content of sediments of seven headwater lakes in Minnesota and Wisconsin. They estimated that $25 \%$ of the atmospheric mercury deposition on the land is exported to the lake. Mercury is concentrated by small life forms in bodies of water which are eaten by fish. The high concentrations of mercury in fish represent a hazard to humans who may eat the fish. The World Health Organization recommended daily intake limit for mercury is 0.43 micrograms of mercury/kilogram of body weight (Nriagu et al. 1992).

Vogg et al. (1986) used the fact that metallic mercury (zero valence) is poorly removed from gas streams by condensation, to help in the identification of species of mercury produced by incineration of municipal waste (which produces mostly mercury in the chloride form). Otani et al. (1984) reported that mercury was found to exist mostly as a vapor even when the mercury vapor concentration is 200 times as high as the saturated vapor pressure. They reported that their study showed particulate mercury was present as about $2 \%$ of the total mercury at a supersaturation of $260 \%$. In a later study (Otani et al. 1986) showed that very little mercury vapor is adsorbed upon electrostatic precipitator ash at high temperature.

Hall et al. (1990) showed that 20 to $30 \%$ of the mercury injected into a propane flame is oxidized after 0.8 seconds in the furnace and the flue gas duct. In the presence of hydrogen chloride, most of the mercury is oxidized after 0.8 seconds. The reaction product was assumed to be mercuric chloride which is known to be highly soluble in water. Significantly, a "rereduction" of the mercury occurs when the temperature has decreased below $390^{\circ} \mathrm{F}\left(199^{\circ} \mathrm{C}\right)$. This is significant for the method of mercury capture we used in the work described in this report. 
Kistler et al. (1987) conducted tests to determine the partition of heavy metals during the pyrolysis of sewage sludge. They showed that the mercury was completely evaporated from sewage sludge at the lowest temperature investigated $\left(660^{\circ} \mathrm{F}\right.$ or $350^{\circ} \mathrm{C}$ ). They also reported that the collection of the evaporated mercury from the gas stream requires efficient condensation and scrubbing and, also, further treatment.

Although the studies indicate that nearly all of the chlorine in the coal is emitted in the flue gas (as chlorides) we have not focused upon control of chlorine because it is not as toxic as mercury and the heavy metals. Also, EPA is not expected to limit emissions of chlorine from coal-fired power plants.

Sampling and analyses of mercury and other trace toxics are difficult. Mercury is difficult to measure accurately because it is present in very low concentrations in coal. Mercury levels in U.S. coals vary from about 0.01 to $8 \mathrm{ppm}$ (Chow et al. 1992). Typical values are about $0.24 \mathrm{ppm}$ for Appalachian coals, $0.14 \mathrm{ppm}$ for Interior Eastern coals, and $0.21 \mathrm{ppm}$ for Illinois Basin coals. Rocky Mountain coals typically contain about $0.06 \mathrm{ppm}$ and Great Plains coals contain about $0.9 \mathrm{ppm}$ of mercury (Jacobsen et al. 1992). Data regarding mercury emissions is suspect because the sampling and analytical methods used may have been unreliable (Chow et al. 1992). The Electric Power Research Institute is currently working on improved sampling and analytical procedures for mercury for use at future test sites. The currently used EPA Method 101A for mercury and Method 29 for multiple metals testing are of questionable validity (Cooper 1993). Western Research Institute's (WRI) experience with use of EPA Method 101A is that the permanganate solution captures about onehalf of the mercury emitted in gases from incineration of municipal waste and the iodine monochloride used in Method 101 captures about $80 \%$ of the mercury, but $\mathrm{SO}_{2}$ quickly consumes the iodine monochloride reagent (Nordin, J.S., personal communication, October 1992).

\section{REMOVAL OF MERCURY FROM POWDER RIVER BASIN COAL}

\section{Approach}

We analyzed coal from the AMAX Eagle Butte mine and char from mild gasification tests (Merriam et al. 1990) and found that most of the mercury is removed from PRB coal at temperatures below 950 to $1140^{\circ} \mathrm{F}\left(510\right.$ to $560^{\circ} \mathrm{C}$ ) (Table 2). However, the gap in the mercury removal data between ambient temperatures and the pyrolysis temperatures that caused about $80 \%$ of the mercury to be removed from coal needed to be better defined to find a method for economical removal of mercury from coal. 
Table 2. Volatile Trace Elements in Powder River Basin Coal and Chars from Pyrolysis, $\mathrm{mg}$ of element/kg of Coal or Char

Arsenic Mercury Selenium

\section{$\underline{\text { Raw Coal }}$}

Sample 1

$0.842 \quad 0.095$

0.562

Sample 2

$<0.50$

0.043

1.00

\section{Pyrolyzed Chars}

Test Temperature, ${ }^{\circ} \mathrm{F} \quad$ Fraction of Coal

$\begin{array}{lrrrrr}\text { MG123 } & 1051 & 0.381 & 1.50 & 0.036 & 1.10 \\ \text { MG125 } & 993 & 0.404 & <0.50 & 0.036 & 1.27 \\ \text { MG126 } & 1146 & 0.397 & 1.00 & 0.027 & 0.80\end{array}$

Removal, wt \% of element in coal not left in char $>25$

80

Our approach to removal of the mercury was centered around the limitations in sampling and analysis in order to acquire data which would be sufficiently accurate to be useful. We are able to analyze mercury in coal using cold vapor atomic absorption spectroscopy (ASTM D3684), but the repeatability of the test is $0.019 \mathrm{ppm}$ and the reproducibility is $0.033 \mathrm{ppm}$ using this method. Since PRB coal contains about $0.07 \mathrm{ppm}$ of mercury, about one-third of the mercury is at a concentration that is below the detection limit. We collected mercury using acid-washed coconut shell activated charcoal because that method was known to collect essentially $100 \%$ (Germani and Zoller 1988) and the standard EPA Methods 101 and 101A were reported to be unreliable. We also knew from our experience with collection of mercury in other work that we wanted to control the temperature of the sample line between the reactor and the activated charcoal adsorption trap. Our primary tool for checking the reliability of data would be closure of mercury balances. Other researchers have considered mercury balances within $20 \%$ of closure to be acceptable data (Brown and Schmidt 1993). 


\section{Description of the Testing System}

We conducted a series of tests using a bench-scale fluidized-bed reactor (Figure 1) to heat minus 16 mesh PRB coal (Table 3). In this reactor a horizontal flow of coal is fluidized by a vertical flow of hot fluidizing gas. The plug-flow of solids permits the reactor to be operated as a nonisothermal bed. The temperature of the coal in the fluidized bed increases as the coal moves horizontally through the reactor. We use the temperature near the outlet of the bed, where the bed temperature is a maximum, to control the system when processing temperature-sensitive materials such as coal that contains mercury. The reactor is equipped with independently controlled heaters along the sides to limit heat losses, but most of the heat is supplied to the coal by the hot fluidizing gas.

Table 3. Composition of Powder River Basin Coal from the Eagle Butte Mine

\begin{tabular}{lcccc}
\hline Sample & $\mathrm{A}$ & $\mathrm{B}$ & $\mathrm{C}$ & $\mathrm{D}$ \\
\hline Proximate Analysis, wt \% & & & & \\
Moisture & 29.2 & 30.5 & 30.6 & 28.8 \\
Ash & 3.0 & 3.1 & 3.0 & 3.0 \\
Volatiles & 32.6 & 31.0 & 30.6 & 31.9 \\
Fixed Carbon & 35.2 & 35.4 & 35.7 & 36.2 \\
Ultimate Analysis, wt \% & & & & \\
Carbon & 74.8 & 73.0 & 71.1 & 71.0 \\
Hydrogen & 6.9 & 5.8 & 6.3 & 5.5 \\
Nitrogen & 0.7 & 0.7 & 0.6 & 1.0 \\
Sulfur & 0.4 & 0.4 & 0.4 & 0.4 \\
Oxygen & 14.2 & 17.0 & 18.6 & 19.1 \\
Forms of Sulfur, wt \% & & & & \\
Pyrite & 0.04 & 0.04 & 0.01 & 0.01 \\
Organic & 0.25 & 0.24 & 0.21 & 0.21 \\
Sulfate & 0.02 & 0.02 & 0.03 & 0.03 \\
Total Sulfur & 0.31 & 0.30 & 0.26 & 0.25 \\
& & & & \\
\hline
\end{tabular}




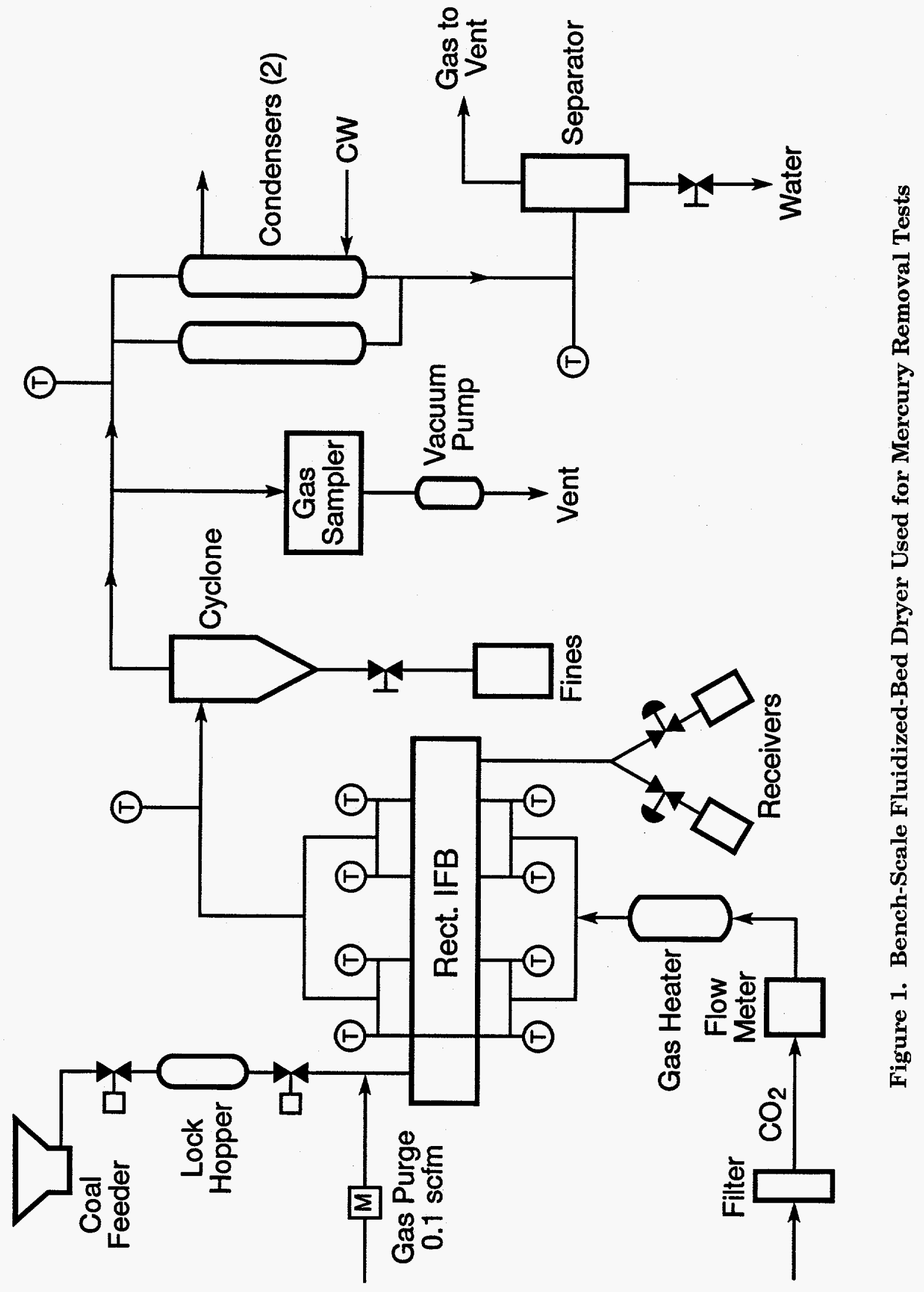


We used an activated carbon trap in a side stream of the effluent gas (Figure 2) to collect mercury from the gas stream. The side stream gas sample lines were heated to avoid condensation of mercury on the surface. The traps were not heated, so even though we expected to capture mercury from the gas stream by adsorption upon activated charcoal, we would also accept any mercury that would condense in the traps. We analyzed the feed coal, fines, dried coal, and activated carbon traps using ASTM D3684 (cold vapor atomic adsorption spectroscopy). We expected the mercury which was driven from the coal to remain in the gas stream and not to condense with the water, but we could not be certain that would happen. Condensed water samples were analyzed using EPA Method 245.1. The method involves reduction of the mercury by reaction with stannous chloride and measurement of the adsorption of light at a wave length of 253.7 nanometers.

We air dried the coal to avoid the problem of having the minus 16 mesh coal compact and cause the variable-speed screw feeder to plug (Table 4). Tests (Table 5) were conducted at various temperatures to determine the response of mercury in the coal.

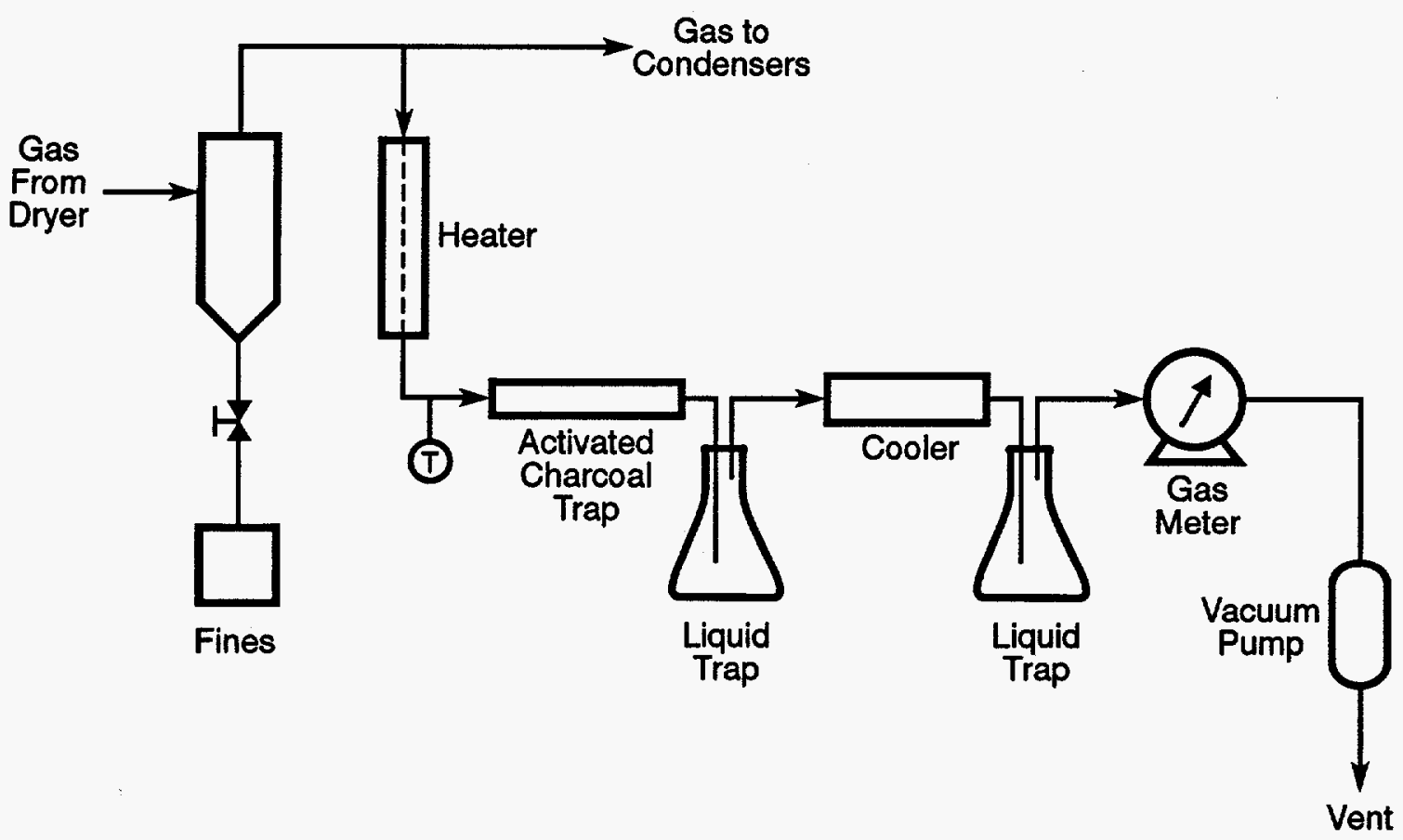

Figure 2. Sampling System Used to Remove Mercury from a Side-Stream of Effluent Gas 
Table 4. Composition of Air-Dried Coal Used for Tests

\begin{tabular}{lcccc} 
Sample & A & B & C & D \\
\hline Moisture, wt \% & 19.4 & 19.6 & 19.6 & 19.5 \\
Mercury $^{\mathrm{a}}$ & 0.069 & 0.053 & 0.064 & \\
Selenium $^{\mathrm{a}}$ & 1.35 & $<1.02$ & $<1.06$ & \\
Arsenic $^{\mathrm{a}}$ & 0.71 & $<0.51$ & $<0.53$ & \\
a $\mathrm{mg}$ of element/kg of coal $^{\mathrm{m}}$ & & & &
\end{tabular}

Table 5. Summary of Conditions Used for Tests to Remove Mercury from Powder River Basin Coal ${ }^{\mathrm{a}}$

\begin{tabular}{|c|c|c|c|c|c|}
\hline Test $^{\mathrm{a}}$ & 112 & 116 & 117 & 118 & 119 \\
\hline Fluidizing Gas Flow, scfm & 9.2 & 10.7 & 10.8 & 10.8 & 10.8 \\
\hline Coal Feed Rate, pph & 13.3 & 18.9 & 17.2 & 23.8 & 18.8 \\
\hline Acid Wash Act. Car. & No & Yes & Yes & Yes & Yes \\
\hline Gas Filtered & No & Yes & Yes & Yes & Yes \\
\hline Maximum Bed Temp ${ }^{\circ} \mathrm{F}$ & Vary & 450 & 327 & 395 & 550 \\
\hline
\end{tabular}

During test 112 the bed temperatures in the reactor were varied and samples of dried coal and corresponding samples of mercury from the gas were collected which represented bed temperatures of $328,390,458$, and $513^{\circ} \mathrm{F}\left(165,199,237\right.$, and $\left.267^{\circ} \mathrm{C}\right)$. Test 113 was limited by variations in the coal feed rate which caused the bed temperature control to fluctuate by an unacceptable amount. A sample of dried coal taken when the bed temperature was about $630^{\circ} \mathrm{F}$ contained less than a detectable amount, which was 0.040 milligrams of mercury/kilogram. Test 114 was abandoned when the coal feeder malfunctioned. The coal feed rate was not adequately controlled during test 115 because a buildup of coal dust in the condensers caused a high pressure in the reactor which the feeder could not overcome. Tests 116 through 119 all met the objectives of the individual tests. 
Following test 115 a bag filter was installed between the cyclone and the condensers (Figure 1) in the reactor system. Gas samples reported here were withdrawn from the effluent stream after the gas passed through the filter. However, a few comparison tests indicated that the difference in mercury content of the filtered and unfiltered gas was too small to detect using our methods.

The mercury content of the gas stream was calculated from the weight of mercury in the traps and the volume of gas used to deposit the mercury. In our early tests, some traps were overloaded causing mercury to pass through. The leakage of mercury through the traps was determined by dividing the activated carbon beds into halves and analyzing the inlet and outlet halves (Figure 3). In this graphical technique, the mercury content of the activated charcoal is plotted using 0.25 as the average position of the first half of the trap and 0.75 as the average of the second half. A line is extrapolated through these midpoint values to the outlet of the trap (position 1.0). If the line crosses the outlet position at a mercury value greater than zero the trap has been overloaded and mercury has probably leaked through. This technique assumes that the adsorption isotherm is linear across the range tested. During tests 117,118 , and 119 we used two traps in series, resulting in determination of the mercury content in the activated carbon in four quadrants. We avoided overloading traps in later tests by estimating the quantity of mercury to be released at test conditions and adjusting the volume of gas passed through each activated carbon bed.

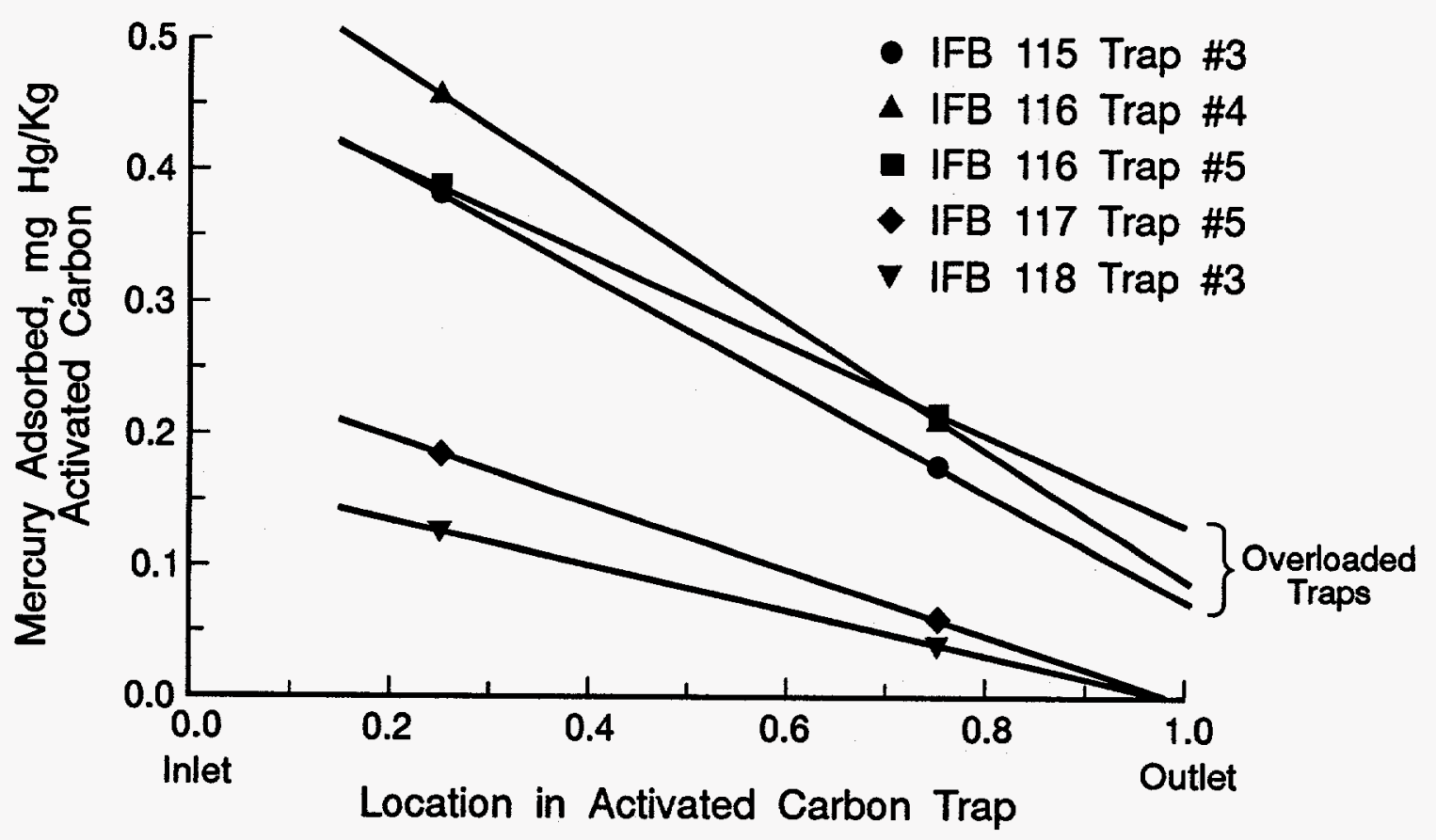

Figure 3. Analyses and Plots Used to Detect Breakthrough of Mercury 


\section{RESULTS}

We found the quantity of mercury released from the coal is predicted by the temperature at which the coal is processed. Figure 4 was developed as the tests progressed for use in estimating the volume of gas needed for good samples. We wanted to load the inlet end of the activated carbon traps to about 0.2 to 0.4 milligrams of mercury/kilogram of carbon to get good detection in analysis without overloading our traps. (Overloading traps was less of a concern after we began to use two traps in series.)

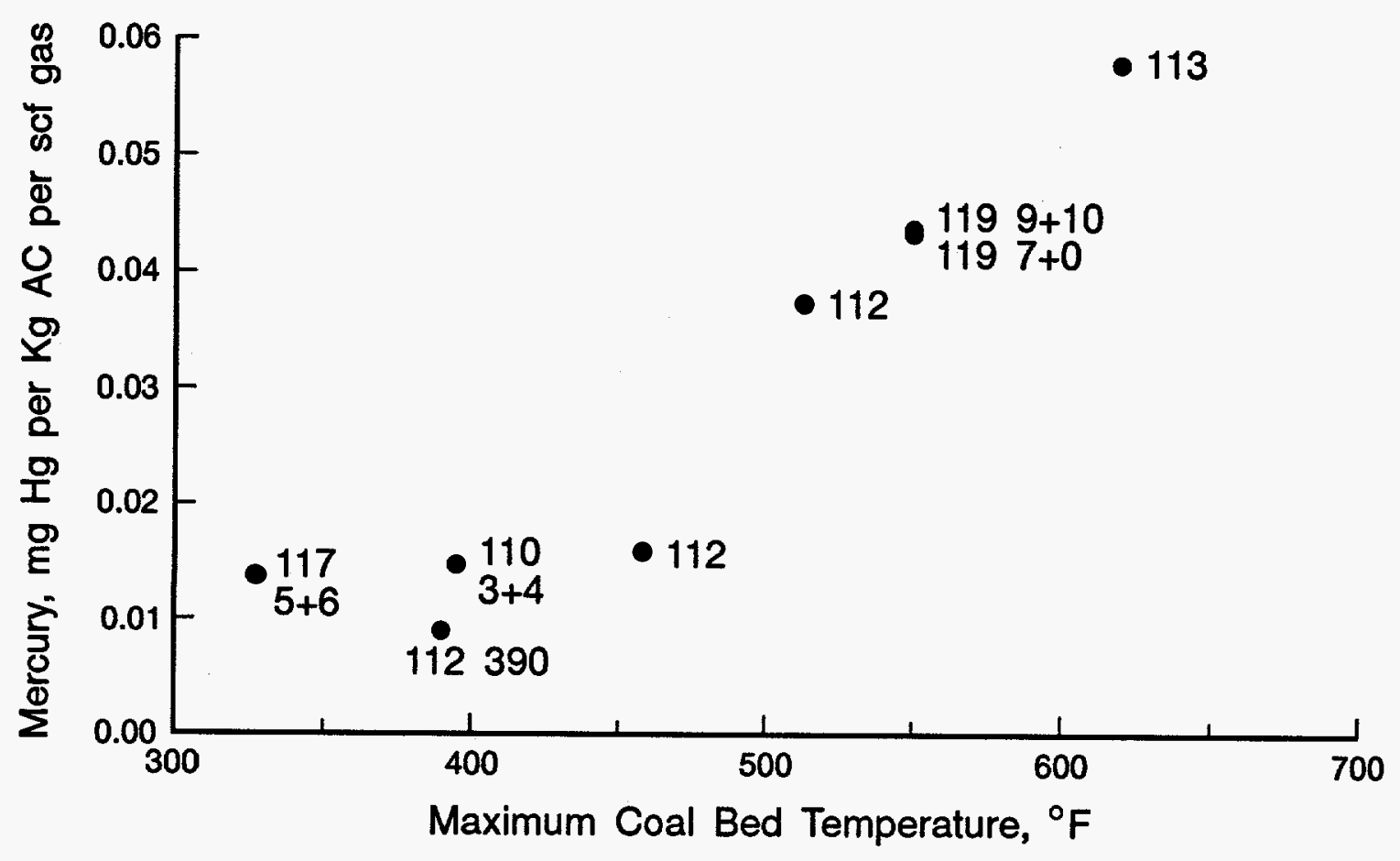

Figure 4. Temperature at which Mercury is Released from Powder River Basin Coal

Coal balances (Table 6) show the partitioning of the coal into dried coal, fines, water, and gas. A comparison of the partitioning of the mercury (Table 7) shows how much mercury was depleted from the coal at the various test conditions and into which components the mercury was concentrated (Table 8).

Our primary tool for evaluation of the distribution of the mercury removed from the coal was closure of mercury balances (Table 7). The mercury remained in the fines which were elutriated from the bed, although the fines were dried to almost zero water content, because the fines are elutriated from the cooler inlet end of the bed. 
Table 6. Coal Balances for Tests Conducted to Remove Mercury from Powder River Basin Coal, kg

\begin{tabular}{llllll}
\hline Test & 112 & 116 & 117 & 118 & 119 \\
\hline Feed Coal & 35.234 & 42.800 & 32.000 & 13.007 & 32.000 \\
Dried Coal & 28.417 & 33.210 & 24.591 & 9.293 & 21.927 \\
Fines & 1.232 & 2.133 & 1.653 & 1.067 & 2.574 \\
Water & 6.250 & 5.823 & 4.479 & 1.541 & 5.586 \\
Gas & 1.057 & 1.284 & 0.320 & 0.260 & 1.280 \\
Total Out & 36.956 & 42.450 & 31.040 & 12.161 & 31.367 \\
Closure, \% & 104.9 & 99.2 & 97.0 & 93.5 & 98.0 \\
\hline
\end{tabular}

Table 7. Mercury Balances for the Tests Conducted to Remove Mercury from Powder River Basin Coal, mg of Mercury

\begin{tabular}{lccccc}
\hline Test & 112 & 116 & 117 & 118 & 119 \\
\hline Feed Coal & 2.185 & 2.654 & 1.984 & 0.806 & 1.984 \\
Dried Coal & 1.362 & 0.996 & 1.672 & 0.706 & 0.746 \\
Fines & 0.113 & 0.196 & 0.121 & 0.078 & 0.162 \\
Water & NA & $<0.012$ & $<0.009$ & $<0.003$ & $<0.011$ \\
Gas & 0.165 & 0.459 & 0.289 & 0.102 & 0.709 \\
Total Out & 1.640 & 1.660 & 2.082 & 0.889 & 1.617 \\
Closure, \% & 75.1 & 62.5 & 104.9 & 110.2 & 81.5 \\
\hline
\end{tabular}


Table 8. Comparison of Distribution of Coal Components and Mercury, \% of Coal or Mercury in Feed

\begin{tabular}{lccccccc}
\hline Test & \multicolumn{2}{c}{ Feed } & $\begin{array}{c}\text { Dried } \\
\text { Coal }\end{array}$ & Fines & Water & Gas & $\begin{array}{c}\text { Total } \\
\text { Out }\end{array}$ \\
\hline 112 & Coal & 100.0 & 80.7 & 3.5 & 17.7 & 3.0 & 104.9 \\
& Mercury & 100.0 & 62.3 & 5.2 & NA & 7.6 & 75.1 \\
116 & Coal & 100.0 & 77.6 & 5.0 & 13.6 & 3.0 & 99.2 \\
& Mercury & 100.0 & 37.5 & 7.4 & $<0.4$ & 17.3 & 62.5 \\
117 & Coal & 100.0 & 76.8 & 5.2 & 14.0 & 1.0 & 97.0 \\
& Mercury & 100.0 & 84.3 & 6.1 & $<0.5$ & 14.6 & 104.9 \\
118 & Coal & 100.0 & 71.4 & 8.2 & 11.8 & 2.0 & 93.5 \\
& Mercury & 100.0 & 87.6 & 9.7 & $<0.4$ & 12.7 & 110.3 \\
& Coal & 100.0 & 68.5 & 8.0 & 17.5 & 4.0 & 98.0 \\
\hline \multirow{2}{*}{119} & Mercury & 100.0 & 37.6 & 8.2 & $<0.6$ & 35.7 & 81.5 \\
\hline
\end{tabular}

The gas leaves the reactor at temperatures varying from about $250^{\circ} \mathrm{F}\left(121^{\circ} \mathrm{C}\right)$ for the lower-temperature runs, to about $370^{\circ} \mathrm{F}\left(188^{\circ} \mathrm{C}\right)$ for the higher-temperature runs. These temperatures are hot enough to dry the fines in the effluent gas line, but are not sufficiently high to remove substantial amounts of mercury from the fines. Less than $0.5 \%$ of the mercury was condensed with the water. At temperatures of about $300^{\circ} \mathrm{F}\left(149^{\circ} \mathrm{C}\right)$ or slightly higher most of the mercury remained in the dried coal and 10 to $20 \%$ of the mercury was found in the effluent gas stream. At temperatures near $500^{\circ} \mathrm{F}\left(260^{\circ} \mathrm{C}\right.$ ) about 30 to $40 \%$ of the mercury remained in the dried coal and 40 to $50 \%$ was found in the effluent gas stream.

The closure for the coal balance for test 118 is low because recovery of condensed water from the effluent gas is low. Fortunately, the condensed water contains very little mercury. The comparison of the distribution of mercury relative to the components of the coal shows a large variation as the temperature is changed from about $300^{\circ} \mathrm{F}\left(149^{\circ} \mathrm{C}\right)$ to about $550^{\circ} \mathrm{F}\left(288^{\circ} \mathrm{C}\right)$ (Table 8). At temperatures near the lower end of the range little of the mercury is driven from the coal. At higher temperatures, larger portions of the mercury are driven into the gas. Almost none of the mercury is condensed with the product water. The mercury content of the fines is roughly equal to the mercury content of the feed coal because the fines are 
elutriated from the bed before the temperature is increased sufficiently to drive mercury from the fines. However, nearly all of the water is driven off of the fines.

The removal of mercury at different temperatures (Figure 5) is the basis for our process to remove mercury from PRB coal. The water can be removed from coal at a temperature of less than $300^{\circ} \mathrm{F}\left(149^{\circ} \mathrm{C}\right)$ by drying in the presence of a noncondensible gas at low pressure (Figure 6). The emission of mercury (Figure 5) coincides with removal of a relatively dry gas stream (Figures 7 and 8) by partial decarboxylation of the coal. Although the mercury does not condense (mercury at zero valence is insoluble in water) with the water, the recovery and capture of the mercury is simpler when no water is present.

When the mercury is captured in low-temperature scrubbing systems (such as a solution of sodium sulfide) the water must be condensed and removed from the system to cool the gas. Water vapor reduces the adsorption capacity of activated carbon and other surface-dependent adsorbents for mercury. Thus, the presence of large amounts of water increases the cost and reduces the efficiency of systems which can potentially be used to capture mercury from the gas stream.

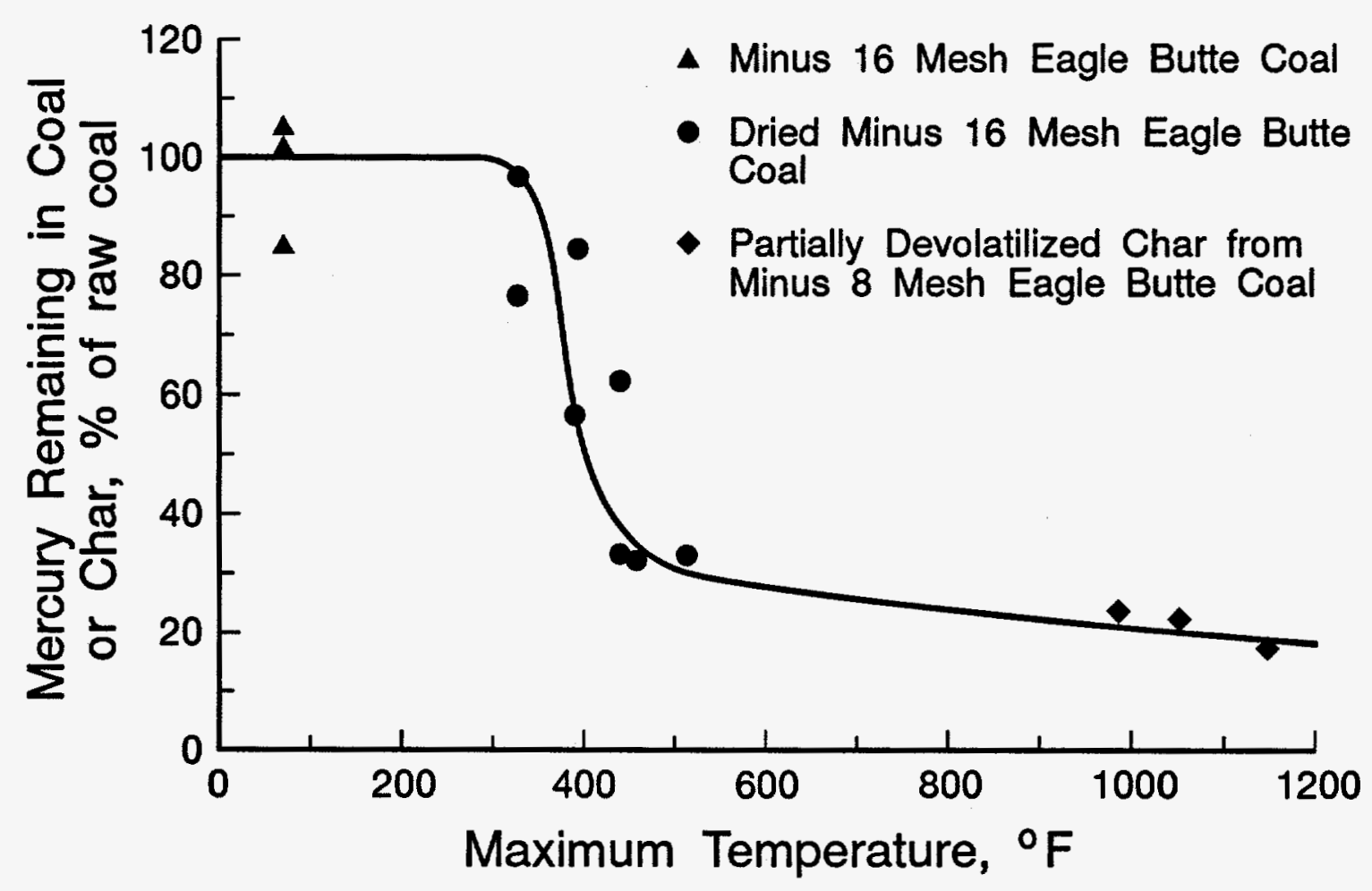

Figure 5. Most of the Mercury in Powder River Basin Coal is Driven from the Coal at Temperatures of 300 to $550^{\circ} \mathrm{F}$ 


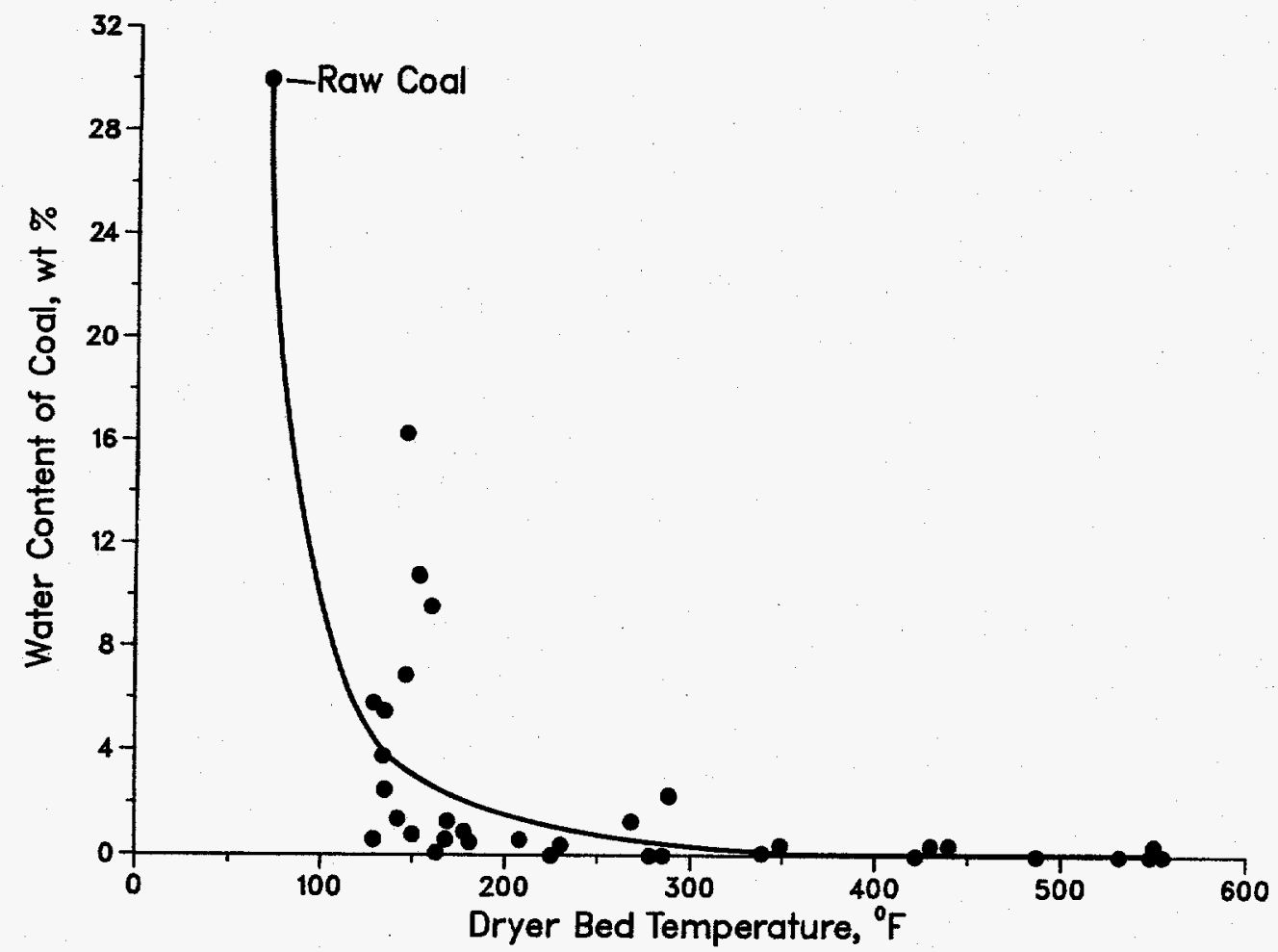

Figure 6. Removal of Water Using a Fluidized-Bed Dryer (Merriam et al. 1990)

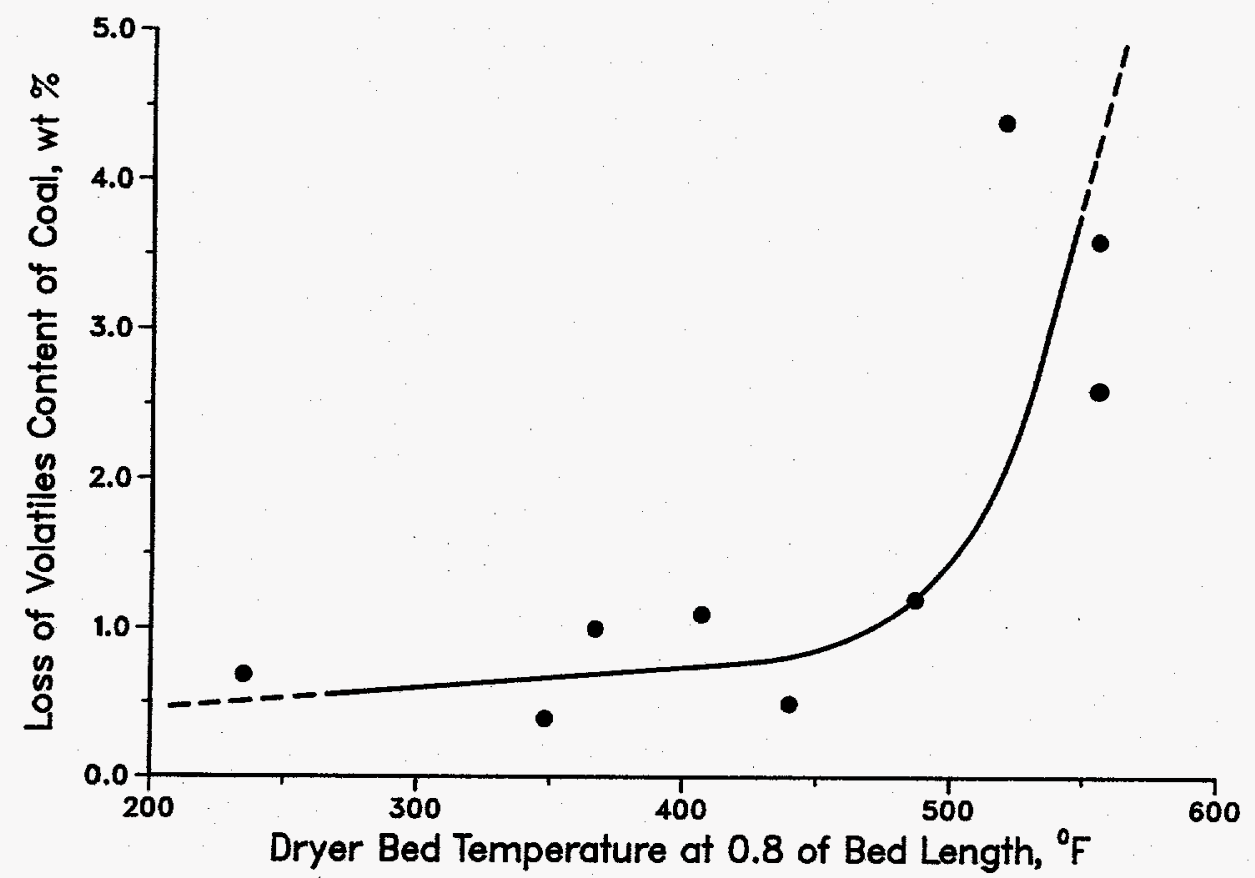

Figure 7. Partial Decarboxylation of Powder River Basin Coal (Merriam et al. 1990) and Removal of Mercury 


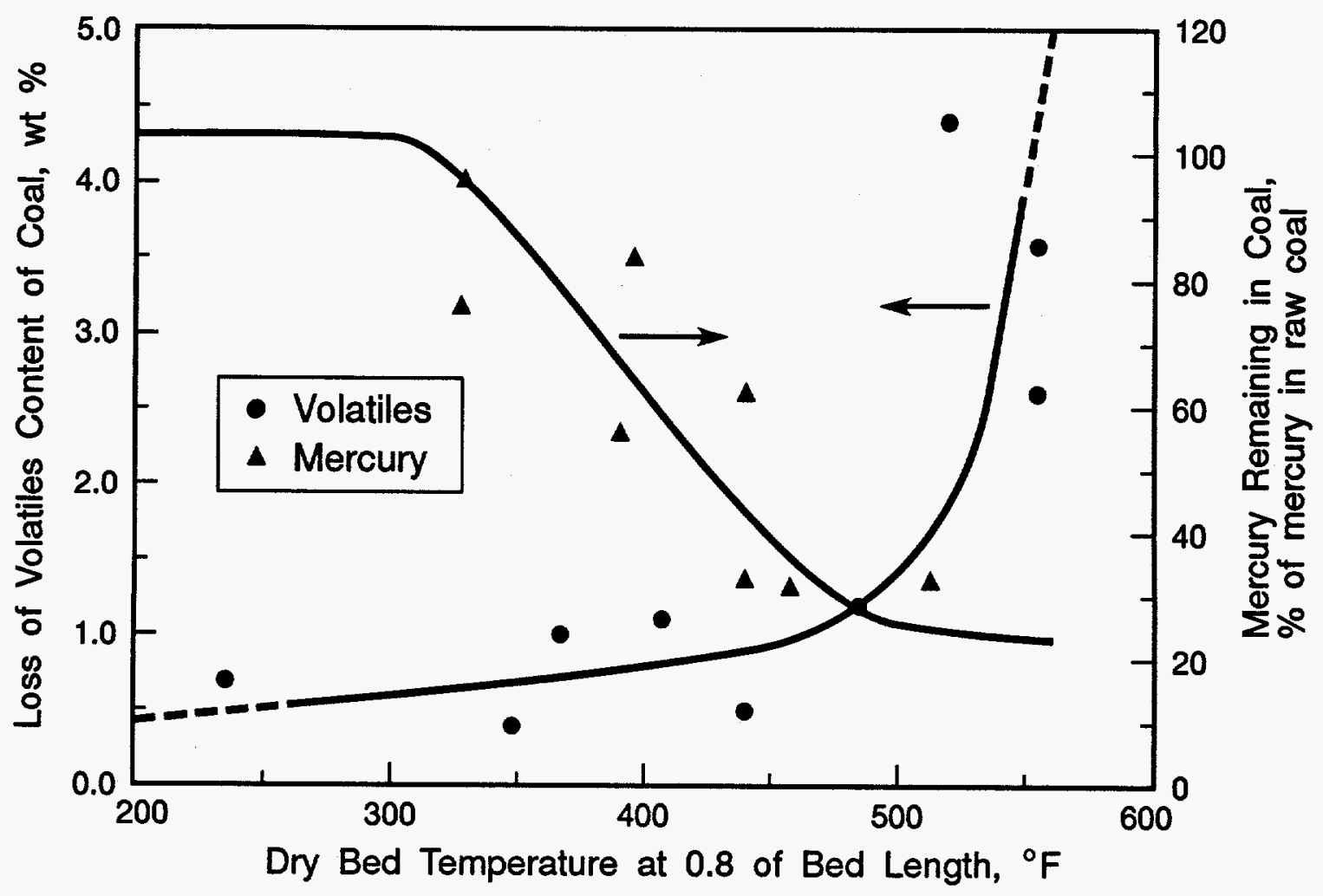

Figure 8. Removal of Mercury with Partial Decarboxylation

\section{PROPOSED MERCURY REMOVAL PROCESS}

\section{Proposed Process}

In our proposed process mercury is removed from coal by heating the coal to a temperature of about $550^{\circ} \mathrm{F}\left(288^{\circ} \mathrm{C}\right)$ (Figures 9 and 10). It is preferred, but not necessary, to dry coals containing large amounts of water before the mercury is driven out. The mercury may be driven from the coal as part of another operation such as drying, pyrolysis, calcining, hot briquetting, pulverizing, or other processing. Lowrank coals contain enough oxygen that partial decarboxylation can supply gas to transport mercury a way from the coal particles for capture by a medium outside of the coal bed. The process also envisions use of a gas stream introduced to carry mercury away from the coal for capture and disposal. The gas may be natural gas, gas derived from coal, carbon dioxide, nitrogen, recycle gas, flue gas, air, steam, or any other gas which is compatible with the conditions under which the mercury is being removed. The gas may also serve added purposes in the system, such as carrying heat to the process, carrying dust or vapors from the reactor, fluidizing particles, reacting with other components, or any of numerous functions. 


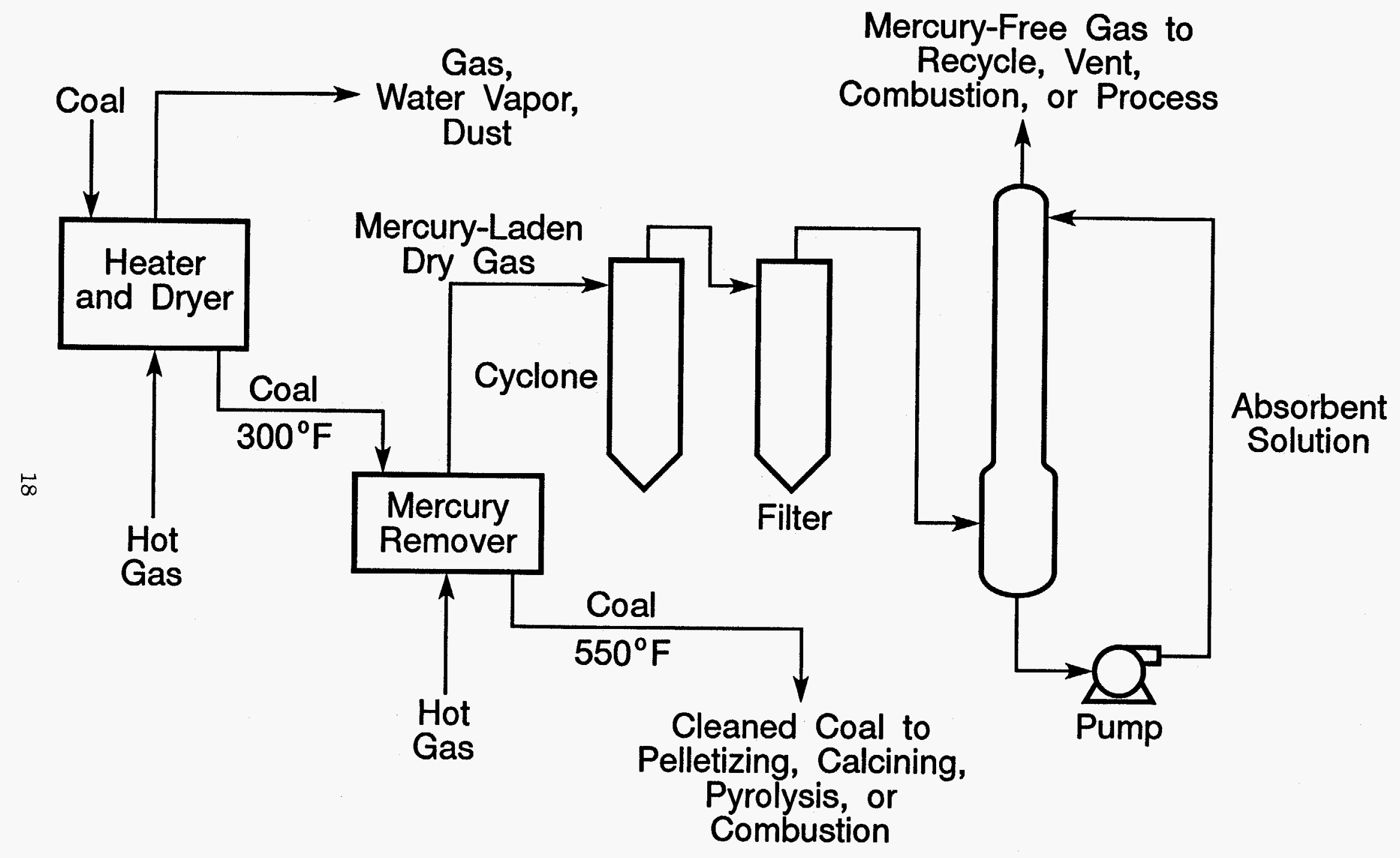

Figure 9. Removal of Mercury and Capture by Low-Temperature Scrubbing 


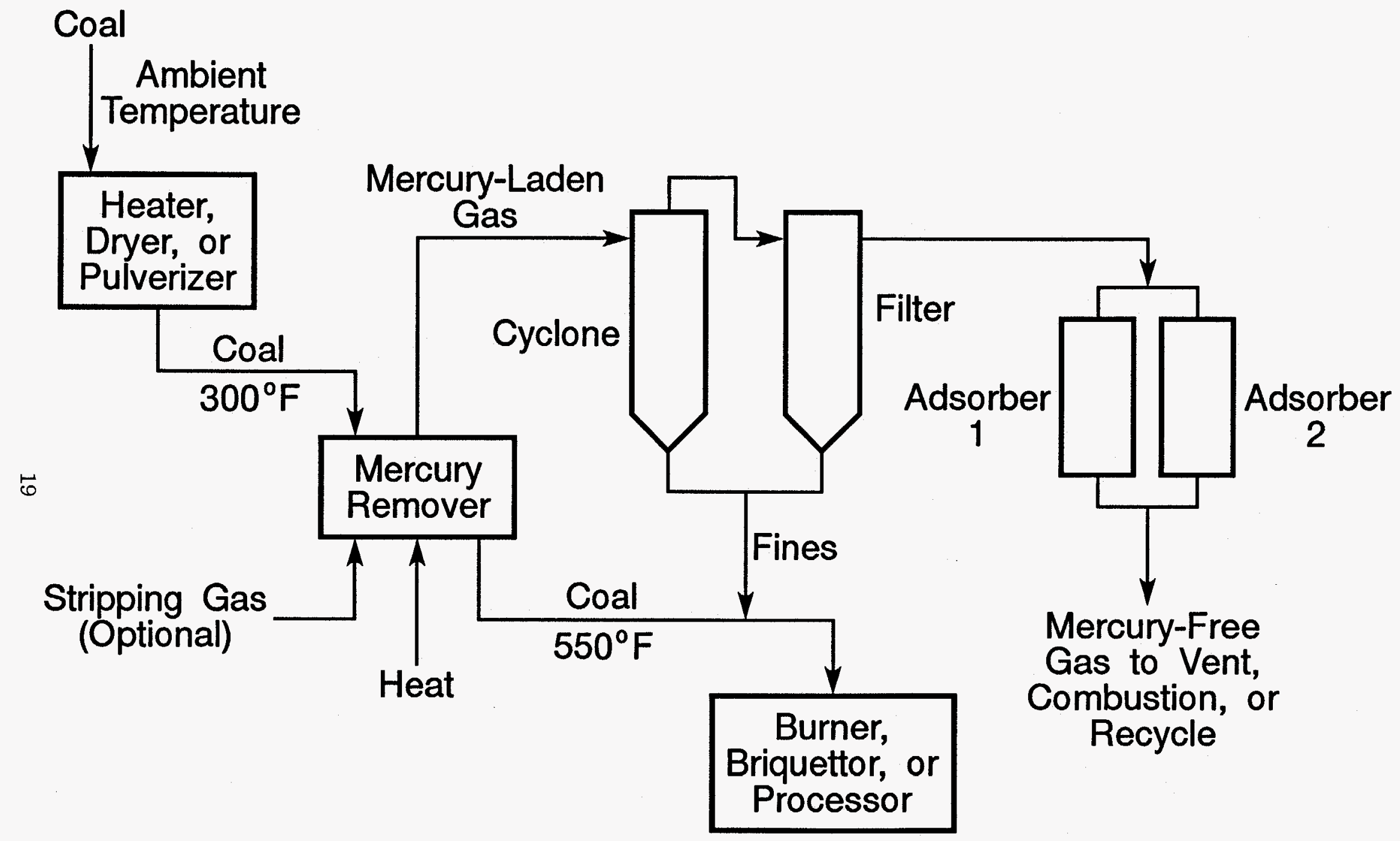

Figure 10. Removal of Mercury and Capture by Medium-Temperature Adsorption 


\section{Capture of Mercury}

There are many known methods of capturing mercury from a gas stream. Kasai and coworkers (U.S. Patent 3,876,393 dated April 8, 1975) outline prior knowledge for removing mercury from gases. They classify the methods as wet processes and dry processes. Wet processes include washing with chlorine water to convert mercury to the water soluble mercury chloride. Large amounts of chlorine are consumed when $\mathrm{SO}_{2}$ is present in the gas. The wet processes also include washing the gas with an acidic permanganate solution, which is known to be an ineffective method.

The dry processes which Kasai and coworkers discuss include use of various adsorbents such as activated carbon impregnated with amalgam forming metals like silver, gold, or copper. Sodium and nickel are also known to form amalgams with mercury. Elemental sulfur deposited upon activated carbon (U.S. Patent 3,193,987) or aluminum oxide impregnated with silver metal (U.S. Patent $3,257,776$ ) as well as numerous sulfide or permanganate compounds have been proposed. However, these substances are of limited use because $\mathrm{SO}_{2}$ and halogens and their compounds interfere with the adsorption of mercury.

The Kasai patent describes use of activated carbon impregnated with sulfuric acid. Halogen and $\mathrm{SO}_{2}$ containing gases are claimed to not interfere with adsorption of mercury. They report the use of steam at $390^{\circ} \mathrm{F}\left(199^{\circ} \mathrm{C}\right)$ to strip the mercury from the acid containing carbon, and claim that the mercury can be condensed with the water from the stripping.

Otani et al. (1988) describe the use of sulfur impregnated activated carbon, active alumina, and zeolite. They report that the presence of the sulfur increases the adsorption capacity of the alumina and the zeolite by several orders of magnitude. Sinha and Walker (1972) report that deposition of sulfur on an adsorbent increases the capacity of the adsorbent at a temperature of $300^{\circ} \mathrm{F}\left(149^{\circ} \mathrm{C}\right)$ because the mercury reacts to form mercuric sulfide (which is stable to about $900^{\circ} \mathrm{F} / 482^{\circ} \mathrm{C}$ ). The sulfur does little to increase the capacity of the adsorbent at lower temperatures.

Chow et al. (1992) report that it appears that temperature plays an important role in mercury emissions. They think the likely explanation is that mercury is condensing on surfaces at the lower temperatures and remaining volatile at the higher temperatures. They cite reports of use of activated carbon to increase the removal of mercury from gas streams. Chow et al. also report the use by Japanese authors of sodium hypochlorite in a wet lime flue-gas desulfurization system to accomplish 95 to $100 \%$ removal of mercury from flue gas from a municipal waste incinerator. Chemical removal of mercury by sodium sulfide scrubbing is reported to convert both vaporous mercury and mercuric chloride to the stable mercuric sulfide. 


\section{DISCLAIMER}

WRI makes no warranty either express or implied regarding the use of the information contained in this report. The opinions expressed reflect the best judgement of the authors and do not imply concurrence by WRI. The use of specific brand names of equipment or processes is for information only and does not imply endorsement of said items. 


\section{REFERENCES}

Akers, D., and R. Dospoy, 1992, Use of Coal Cleaning to Reduce Air Toxics, presented at the SME Annual Meeting-Phoenix, Arizona, Feb. 24-27. SME Preprint 92113.

Braine, B., and C. Mann, 1992, Emission Allowances: Market Opportunities and Strategies.Proceedings of the Tenth Annual Coal Market Strategies Conference, Western Coal Council, Denver, CO.

Brown, T. D., and C. E. Schmidt, 1993, Characterization of Hazardous Air Pollutants from Coal-Fired Electric Utilities, Am. Chem. Soc., Presented at 205th national Meeting, Denver, CO, 3-93.

Chow, W., L. Levin, and M. J. Miller, 1992, Managing Hazardous Air Pollutants: EPRI's Pisces R \& D Project. Presented at Canadian Electrical Association, Vancouver, B. C. March 1992.

Cooper, J. A., 1993, Recent Advances in Sampling and Analysis of Coal-Fired Power Plant Emissions for Air Toxic Compounds, Preprints of Am. Chem. Soc. 205th National Meeting, Denver.

Electric Power Research Institute, 1992, Nitrogen and Trace Element Removal from Coal. Electric Power Research Institute, RFP 8003, Palo Alto, CA.

Fitzgerald, W. F., R. P. Mason, and G. M. Vandal, 1991, Water Air Soil Pollut., 56: 745-767.

Germani, M., and W. H. Zoller, 1988, Vapor-Phase Concentrations of Arsenic, Selenium, Bromine, Iodine, and Mercury in the Stack of a Coal-Fired Power Plant, Environ. Sci. Technol., 22: 1079-1085.

Hall, B., O. Lindqvist, and E. Ljungstrom, 1990, Mercury Chemistry in Simulated Flue Gases Related to Waste Incineration Conditions, Environ. Sci. Technol. 24(1): 108-111.

Jacobsen, P. S., M. B. Blinn, E. I. Wan, and M. A. Nowak, 1992, The Role of Coal Preparation in the Precombustion Control of Hazardous Air Pollutants, Coal Prep 92, Am. Min. Congr.

Kistler, R. C., F. Widmer, and P. H. Bruner, 1987, Behavior of Chromium, Nickel, Copper, Zinc, Cadmium, Mercury, and Lead During the Pyrolysis of Sewage Sludge, Environ. Sci. Technol., 21: 704-708. 
Lindqvist, O. 1986, Fluxes of Mercury in the Swedish Environment: Contributions from Waste Incineration, Waste Mgmt. and Research, 4: 35-44.

Merriam, N. W., C. Y. Cha, T. W. Kang, and M. B. Vailliancourt, 1990, Development of an Advanced Continuous Mild Gasification Process for the Production of CoProducts, Topical Report for Task 4, Mild Gasification Tests-System Integration Studies. Laramie, WY, WRI Report to DOE, WRI-91-R023.

Nater, E. A., and D. F. Grigal, 1992, Regional Trends in Mercury Distribution Across the Great Lakes States, North Central USA, Nature, 358: 139-141.

Nriagu, J. O., W. C. Pfieffer, O. Malm, and G. Mierle, 1992, Mercury Pollution in Brazil, Nature, 356: 389 (April 2).

Otani, Y., H. Emi, C. Kanaoka, and S. Matsui, 1984, Behavior of Metal Mercury in Gases, Environ. Sci. Technol., 18: 793-796.

Otani, Y., C. Kanaoka, C. Usui, S. Matsui, and H. Emi, 1986, Adsorption of Mercury on Particles, Environ. Sci. Technol., 20: 735-738.

Otani, Y., H. Emi, C. Kanaoka, I. Uchijima, and H. Nishino, 1988, Removal of Mercury Vapor from Air with Sulfur-Impregnated Adsorbents. Environ. Sci. Technol., 22(6): 708-711.

Sinha, R. K., and P. L. Walker Jr., 1972, Removal of Mercury by Sulfurized Carbons. Carbon, 10: 754-756.

Slemr, F., and E. Langer, 1992, Increase in Global Atmospheric Concentrations of Mercury Inferred from Measurements Over the Atlantic Ocean, Nature, 355: 434-436 (January 30).

Swain, E. B., D. R. Engstrom, M. E. Brigham, T. A. Henning, and P. L. Brezonik, 1992, Increasing Rates of Atmospheric Mercury Deposition in Midcontinental North America, Science, 257: 784-787.

U.S. National Committee for Geochemistry, 1980, Trace-Element Geochemistry of Coal Resource Development Related to Environmental Quality and Health. National Academy Press, Washington D.C.

Vogg, H., H. Braun, M. Metzger, and J. Schneider, 1986, The Specific Role of Cadmium and Mercury in Municipal Solid Waste Incineration, Waste Mgmt. and Research, 4: 65-74. 